Research article

\title{
Menopausal hormone therapy after breast cancer: a meta-analysis and critical appraisal of the evidence
}

\author{
Nananda F Col${ }^{1}$, Jung A Kim² and Rowan T Chlebowski ${ }^{3}$
}

\author{
1Brown Medical School and Harvard University, Providence, Rhode Island, USA \\ 2Department of Nursing, Hanyang University, Seoul, Korea \\ ${ }^{3}$ Harbor-UCLA Research and Education Institute, Torrance, California, USA \\ Corresponding author: Nananda F Col, ncol@lifespan.org
}

Received: 3 Feb 2005 Revisions requested: 18 Mar 2005 Revisions received: 6 Apr 2005 Accepted: 8 Apr 2005 Published: 19 May 2005

Breast Cancer Research 2005, 7:R535-R540 (DOI 10.1186/bcr1035)

This article is online at: http://breast-cancer-research.com/content/7/4/R535

(c) $2005 \mathrm{Col}$ et al.; licensee BioMed Central Ltd.

This is an Open Access article distributed under the terms of the Creative Commons Attribution License (http://creativecommons.org/licenses/by/ 2.0), which permits unrestricted use, distribution, and reproduction in any medium, provided the original work is properly cited.

\begin{abstract}
Introduction Menopausal hormone therapy $(\mathrm{HT})$ is typically withheld from breast cancer survivors because of concerns about risk for recurrence. Our objectives were to estimate the effects of $\mathrm{HT}$ on recurrence in breast cancer survivors and to examine the reliability of these estimates.
\end{abstract}

Methods In a systematic review of the literature we identified all reports of HT use in breast cancer survivors that included comparison groups. Study design features that might affect selection of participants, detection of recurrence, and manuscript publication were assessed. The relative risks for breast cancer recurrence associated with HT were combined with random effects models.

Results Two randomized and eight observational studies included 1,316 breast cancer survivors who used $\mathrm{HT}$ and 2,839 nonusers. In the observational studies, HT users were younger and more commonly node negative; only two reported balanced restaging for $\mathrm{HT}$ and control groups. Randomized trials suggest that $\mathrm{HT}$ increased the risk for recurrence (relative risk 3.41, 95\% confidence interval 1.59-7.33), whereas observational studies suggest that HT decreased this risk (relative risk 0.64, 95\% confidence interval 0.50-0.82).

Conclusion Results from observational studies of HT conducted in breast cancer survivors are discrepant with results from randomized trials. Observational studies of HT use in breast cancer survivors have design limitations that cannot be controlled for using standard statistical methods. Therefore, the randomized clinical trial data provide the only reliable estimates of the effect of HT use on recurrence risks in breast cancer survivors.

\section{Introduction}

Most breast cancer survivors are menopausal either at diagnosis or as a result of premature therapy-induced menopause, and they frequently experience climacteric symptoms [1]. Menopausal hormone therapy $(\mathrm{HT})$, either with estrogen alone or with combined estrogen and progestin, relieves estrogen deficiency symptoms [2] but it is commonly withheld from women with diagnosed breast cancer because of concerns regarding an increased risk for recurrence [3].

The available data from observational studies indicate that use of HT is associated with increased risk for breast cancer [4]. In postmenopausal women, the randomized Women's Health Initiative HT trials found an increased risk for breast cancer with estrogen plus progestin [5] but not with unopposed estrogen [6]. An apparent reduction in risk seen during the first 2 years of combination HT was attributed to a masking of breast cancer detection, with a higher risk for more advanced breast cancers subsequently [5]. In breast cancer survivors, observational studies have consistently reported similar or lower risks for recurrence among women using HT as compared with nonusers [7], albeit with methodological weaknesses [8]; this has been interpreted as evidence of the safety or perhaps benefit of HT in women with breast cancer. However, the first large randomized trial in this population reported that HT significantly increased the risk for recurrence [9].

The objectives of this meta-analysis were to estimate the impact HT has on recurrence risk among observational and 
randomized studies, and to examine the reliability of these estimates.

\section{Materials and methods}

A previous Medline search from 1966 to 1999 [7] was updated to February 2004 using the medical subject headings 'breast neoplasm', 'neoplasm recurrence', 'estrogens', 'estrogen replacement therapy', 'hormone replacement therapy', and 'estradiol', and reference lists of abstracted manuscript and protocols were reviewed. Only studies that included women with invasive breast cancer who received oral $\mathrm{HT}$, that had an explicitly defined comparison group, and that reported breast cancer recurrences were included. Studies that reported overlapping or redundant data were excluded [1016], as were those that did not adequately describe the selection or composition of control groups $[17,18]$ or that included only topical hormones [19].

Two of the authors (NFC and JAK) independently abstracted data on the following variables: sample size, age at diagnosis and at trial induction, tumor stage, nodal status, estrogen and progesterone receptor status, disease-free interval (DFI) between initial breast cancer diagnosis and initiation of HT, type and duration of HT used, follow up after initiation of HT, and number and timing of breast cancer recurrences.

Each study was systematically reviewed for features that could introduce bias, including procedures for identifying participants, whether institutional review board approval and/or informed consent was obtained, whether risk factors for recurrence were similar at diagnosis, and whether restaging before entry (to exclude metastatic disease) and duration of follow up were similar for HT users and nonusers. Observational studies were classified as 'clinical experiences' if one or more study authors provided health care to the cohort with potential participation in the decision to use HT.

When not reported, the follow up after HT initiation was assumed to equal the duration of HT use. Any second breast cancer event (local, regional, or distant recurrence or invasive cancer in either breast) was treated as a recurrence because studies did not consistently make these distinctions.

Relative risk (RR) and 95\% confidence interval (Cl) were calculated for each study for the recurrence rate and mortality rate among $\mathrm{HT}$ users and nonusers. A random effects model was used to estimate the combined RR for randomized and observational studies using Meta-Analyst [13].

\section{Results}

Ten studies were identified, including a total of 1,316 breast cancer survivors who used HT and 2,839 who did not. Of these 10 studies, two were unblinded randomized controlled trials without placebo arms $[9,20]$, one began as a randomized trial but was reported as an observational study and is considered as such here, and seven were observational studies.

\section{Summary of randomized trials}

Both randomized trials were conducted in Europe (one in England and one in Sweden). They involved a total of 445 patients with a mean age of 55.5 years, a mean DFI of 33.2 months, a duration of HT use of 19.9 months, and a mean follow-up period after HT initiation of 25.2 months (Table 1). A total of 36 recurrences and nine deaths occurred during this time in these trials; the pooled RR for the two randomized trials was $3.41(95 \% \mathrm{Cl} 1.59-7.33)$.

\section{Summary of observational studies}

Of the eight observational studies, six were clinical experiences [22-27]. The eight studies involved a total of 3710 patients with a mean age of 59.7 years, a mean DFI of 49.2 months, a duration of HT use of 28 months, and a mean followup period after HT initiation of 57.1 months (Table 1). A combined total of 552 recurrences (109 among HT users) and 460 deaths ( 51 among HT users) occurred in these trials. The pooled RR for the observational studies was $0.64(95 \% \mathrm{Cl}$ 0.50-0.82).

\section{All studies}

Most studies included both combination HT and unopposed estrogens without stratifying risk estimates according to preparation. Three of the observational studies [22,24,25] reported obtaining informed consent but only from women who used HT. Three studies $[20,24,26]$ reported similar restaging for treatment and control groups at the beginning of the observation period, although one of these [26] did not report whether those found to have occult metastasis were excluded. Not all studies reported the DFI for the control groups, but several reported matching control individuals according to DFI $[22,27]$. Prognostic factors for HT users and nonusers differed in most studies (Table 1). On average, HT users were more than 3 years younger than nonusers and were more likely to be node negative. The average duration of HT use was 26.6 months, with an average duration of follow up after initiation of HT of 53 months. The mean DFI was 36.9 months for HT users and 55.6 for nonusers.

Among the $1,191 \mathrm{HT}$ users in nine studies reporting recurrences, 137 (11.7\%) experienced a recurrence of their breast cancer during follow up. Among the 2,477 nonusers in these studies, 451 (18.2\%) had a recurrence. The average annual recurrence rate was $3.3 \%$ (range $0.6-7.1 \%$ ), with substantially higher rates in the randomized trials. Combining all studies yielded a RR for recurrence of 0.84 (95\% Cl 0.54-1.3; Fig. $1)$, with statistically significant heterogeneity $(Q=25.3)$.

\section{Discussion}

Estimates from observational studies of HT among breast cancer survivors suggest that HT prevents breast cancer 
Table 1

\section{Characteristics of 1316 users and 2839 nonusers of hormone therapy}

\begin{tabular}{|c|c|c|c|c|c|c|c|c|c|c|c|c|c|c|}
\hline Study & Treatment & $n$ & $\begin{array}{c}\text { Mean age } \\
\text { (years) }\end{array}$ & Stage & $\begin{array}{l}\text { Nodal } \\
\text { status }\end{array}$ & ER status & PgR status & $\begin{array}{l}\text { Mean DFI } \\
\text { before } \\
\text { HT } \\
\text { (months) }\end{array}$ & $\begin{array}{l}\text { Estrogen alone } \\
(\%)\end{array}$ & $\begin{array}{l}\text { Mean } \\
\text { duration of } \\
\text { HT } \\
\text { (months) }\end{array}$ & $\begin{array}{l}\text { Mean follow- } \\
\text { up after } \\
\text { HT } \\
\text { (months) }\end{array}$ & $\begin{array}{l}\text { Recurrences } \\
(n)\end{array}$ & $\begin{array}{l}\text { Deaths, all } \\
\text { cause } \\
(n)\end{array}$ & $\begin{array}{l}\text { Deaths, primary } \\
\text { tumor }(n)\end{array}$ \\
\hline \multicolumn{15}{|c|}{ Randomized trials } \\
\hline \multirow{2}{*}{$\begin{array}{l}\text { Marsden et } \\
\quad \text { al. (2000; } \\
n=100) \\
{[20]}\end{array}$} & HT & $51^{a}$ & $58^{b}$ & NR & NR & NR & NR & $40^{b}$ & NR & 6 & NR & 2 & NR & NR \\
\hline & No HT & $49^{a}$ & $55^{b}$ & NR & NR & NR & NR & $36^{b}$ & & & NR & 1 & NR & NR \\
\hline \multirow{2}{*}{$\begin{array}{l}\text { Holmberg et } \\
\text { al. (2004; } \\
n=345) \\
{[9]}\end{array}$} & $\mathrm{HT}$ & 174 & 55.5 & NR & $\begin{array}{c}25.9 \%(38) \\
\text { positive }\end{array}$ & ${ }^{86}$ positive $^{c}$ & NR & $31.2^{\mathrm{b}}$ & NR & 24 & $25.2^{\mathrm{b}}$ & 26 & 5 & 3 \\
\hline & No HT & 171 & 55.0 & NR & $\begin{array}{c}21.4 \%(31) \\
\text { positive }\end{array}$ & ${ }^{73}$ positive $^{c}$ & NR & $32.4^{b}$ & & & $25.2^{\mathrm{b}}$ & 7 & 4 & 4 \\
\hline \multicolumn{15}{|c|}{ Observational studies } \\
\hline \multirow[t]{2}{*}{$\begin{array}{c}\text { Ursic-Vrscaj } \\
\text { and Bebar } \\
(1999 ; n \\
=63)[27]\end{array}$} & HT & $21^{d}$ & $47^{b}$ & $\begin{array}{l}1 \mathrm{G} 1 \\
10 \mathrm{G} 2 \\
7 \mathrm{G} 3\end{array}$ & $\begin{array}{l}14 \\
\text { negative, } \\
7 \\
\text { positive }\end{array}$ & $\begin{array}{l}5 \text { positive, } \\
16 \\
\text { negative }\end{array}$ & $\begin{array}{l}8 \text { positive, } \\
13 \\
\text { negative }\end{array}$ & 62 & 4.8 & 28 & 389 & 4 & 09 & 0 \\
\hline & No HT & $42^{d}$ & 48.2 & $\begin{array}{l}7 \mathrm{G} 1 \\
17 \mathrm{G} 2 \\
11 \mathrm{G} 3\end{array}$ & $\begin{array}{l}28 \\
\text { negative } \\
14 \\
\text { positive }\end{array}$ & $\begin{array}{c}18 \text { positive } \\
22 \\
\text { negative }\end{array}$ & $\begin{array}{c}22 \text { positive, } \\
18 \\
\text { negative }\end{array}$ & NR & & & 389 & 5 & 19 & 1 \\
\hline \multirow[t]{2}{*}{$\begin{array}{l}\text { DiSaia et al. } \\
\quad(2000 ; n \\
=487) \\
{[22]}\end{array}$} & $\mathrm{HT}$ & 125 & 55.7 & $\begin{array}{l}17 \text { DCIS } \\
52 \text { stage I } \\
27 \text { stage II } \\
10 \text { stage III } \\
1 \text { stage IV }\end{array}$ & NR & NR & NR & $46^{b}$ & 28 & $22^{\mathrm{b}}$ & $92.1 \mathrm{~g}$ & NR & 49 & NR \\
\hline & No HT & 362 & 55.9 & NR & NR & NR & NR & NR & & & $90.6^{9}$ & NR & 579 & NR \\
\hline \multirow[t]{2}{*}{$\begin{array}{l}\text { O'Meara et } \\
\text { al. (2001; } \\
n=869) \\
{[36]}\end{array}$} & $\mathrm{HT}$ & $174^{d}$ & $63.6^{\mathrm{e}}$ & $\begin{array}{l}91 \text { stage I } \\
51 \text { stage II } \\
20 \text { stage I/ } \\
\text { II } \\
10 \text { stage III } \\
2 \text { stage II/ } \\
\text { III }\end{array}$ & $\begin{array}{l}128 \\
\text { negative, } \\
31 \\
\text { positive }\end{array}$ & $\begin{array}{c}84 \text { positive, } \\
39 \\
\text { negative }\end{array}$ & $\begin{array}{l}71 \text { positive, } \\
45 \\
\text { negative }\end{array}$ & $47.7^{\mathrm{e}}$ & 79 & $15^{b}$ & $44.4^{b, f}$ & 16 & 17 & 5 \\
\hline & No HT & $695^{d}$ & $63.6^{e}$ & $\begin{array}{l}403 \text { stage } \\
\text { I } \\
246 \text { stage } \\
\text { II } \\
3 \text { stage I/II } \\
42 \text { stage III } \\
1 \text { stage II/ } \\
\text { III }\end{array}$ & $\begin{array}{l}470 \\
\text { negative, } \\
175 \\
\text { positive }\end{array}$ & $\begin{array}{l}409 \\
\text { positive, } \\
137 \\
\text { negative }\end{array}$ & $\begin{array}{l}311 \\
\text { positive, } \\
206 \\
\text { negative }\end{array}$ & $47.7^{\mathrm{e}}$ & & & $44.4^{\mathrm{b}, \mathrm{f}}$ & 101 & 115 & 59 \\
\hline \multirow{2}{*}{$\begin{array}{l}\text { Beckmann } \\
\text { et al. } \\
(2001 ; n \\
=185) \\
{[24]}\end{array}$} & HT & 64 & NA & $\begin{array}{l}37 \mathrm{~T} 1 \\
19 \mathrm{~T} 2 \\
8 \mathrm{~T} / 4\end{array}$ & $\begin{array}{l}44 \\
\text { negative, } \\
20 \\
\text { positive }\end{array}$ & $\begin{array}{c}31 \text { positive, } \\
33 \\
\text { negative }\end{array}$ & $\begin{array}{l}34 \text { positive, } \\
30 \\
\text { negative }\end{array}$ & 0 & NA & $33^{b}$ & $37^{b}$ & 6 & 4 & NR \\
\hline & No HT & 121 & NA & $\begin{array}{l}62 \text { T1 } \\
42 \text { T2 } \\
17 \text { T3/4 }\end{array}$ & $\begin{array}{l}76 \\
\text { negative, } \\
45 \\
\text { positive }\end{array}$ & $\begin{array}{l}48 \text { positive, } \\
73 \\
\text { negative }\end{array}$ & $\begin{array}{c}48 \text { positive, } \\
73 \\
\text { negative }\end{array}$ & 0 & & & $42^{\mathrm{b}}$ & 17 & 15 & NR \\
\hline \multirow[t]{2}{*}{$\begin{array}{l}\text { Marttunnen } \\
\text { et al. } \\
(2001 ; n \\
=131) \\
{[26]}\end{array}$} & HT & 88 & 53.4 & $\begin{array}{l}3 \mathrm{DClS} \\
67 \mathrm{~T} 1 \\
17 \mathrm{~T} 2 \\
1 \mathrm{T3}\end{array}$ & $\begin{array}{l}72 \\
\text { negative, } \\
10 \\
\text { positive }\end{array}$ & $\begin{array}{c}57 \text { positive } \\
15 \\
\text { negative }\end{array}$ & $\begin{array}{l}54 \\
\text { positiveg, } \\
13 \\
\text { negativeg }\end{array}$ & 50.4 & 38.6 & 30 & 30 & 7 & 2 & 2 \\
\hline & No HT & 43 & 52.8 & $\begin{array}{l}1 \mathrm{DClS} \\
29 \mathrm{T1} \\
11 \mathrm{T2} \\
2 \mathrm{T3}\end{array}$ & $\begin{array}{l}30 \\
\text { negative, } \\
13 \\
\text { positive }\end{array}$ & $\begin{array}{c}29 \text { positive, } \\
9 \\
\text { negative }\end{array}$ & $\begin{array}{l}30 \\
\text { positive } \\
7 \\
\text { negativeg }\end{array}$ & 50.4 & & & 31.2 & 5 & 3 & 3 \\
\hline \multirow[t]{2}{*}{$\begin{array}{l}\text { Durna et al. } \\
\quad(2002 ; n \\
=1122) \\
{[23]}\end{array}$} & HT & 286 & $56.8^{b}$ & $\begin{array}{l}180 \text { stage } \\
\text { I } \\
64 \text { stage II } \\
22 \text { stage } \\
\text { III/IV }\end{array}$ & NA & NR & NR & $12^{\mathrm{b}}$ & 5.9 & $21^{b}$ & $69.6^{b}$ & 44 & 16 & 13 \\
\hline & No HT & 836 & $64.7^{b}$ & $\begin{array}{c}470 \text { stage } \\
\text { I } \\
191 \text { stage } \\
\text { II } \\
120 \text { stage } \\
\text { III/IV }\end{array}$ & NA & NR & NR & NR & & & $61.2^{\mathrm{b}}$ & 247 & 199 & 122 \\
\hline
\end{tabular}


Table 1 (Continued)

\begin{tabular}{|c|c|c|c|c|c|c|c|c|c|c|c|c|c|c|}
\hline $\begin{array}{l}\text { Vassilopoulo } \\
\text { u-Sellin et } \\
\text { al. (2002; } \\
n=299) \\
{[21]}\end{array}$ & HT & $56^{\mathrm{h}}$ & $56^{b}$ & $\begin{array}{c}9<1 \mathrm{~cm} \\
301-2.5 \\
\mathrm{~cm} \\
15>2.5 \\
\mathrm{~cm}\end{array}$ & $\begin{array}{l}35 \\
\text { negative, } \\
131-3 \\
6>3\end{array}$ & ${ }^{37}$ negative & NR & 105.6 & 100 & $\begin{array}{c}30>5 \\
\text { years, } 20 \\
2-5 \text { years, } \\
62 \text { years }\end{array}$ & 71 & 2 & 1 & 0 \\
\hline & No HT & $243^{h}$ & $53^{b}$ & $\begin{array}{c}38<1 \mathrm{~cm} \\
1341-2.5 \\
\mathrm{~cm} \\
67>2.5 \\
\mathrm{~cm}\end{array}$ & $\begin{array}{c}133 \\
\text { negative, } \\
701-3 \\
33>3\end{array}$ & $\quad 164$ & NR & 99.6 & & & NR & З3 & 2 & 1 \\
\hline \multirow[t]{2}{*}{$\begin{array}{l}\text { Decker et al. } \\
\quad(2003 ; n \\
=554) \\
{[25]}\end{array}$} & HT & 277 & $57.4^{\mathrm{b}}$ & $\begin{array}{c}84 \text { DCIS } \\
124 \text { stage } \\
\text { I } \\
47 \text { stage } \\
\text { IIA } \\
19 \text { stage } \\
\text { IIB } \\
3 \text { stage } \\
\text { IIIA }\end{array}$ & NR & $\begin{array}{l}100 \\
\text { positive, } \\
54 \\
\text { negative }\end{array}$ & $\begin{array}{c}63 \text { positive, } \\
46 \\
\text { negative }\end{array}$ & 43.3 & 48.7 & 44.4 & 49.7 & 30 & 7 & 5 \\
\hline & No HT & 277 & $59.0^{\mathrm{b}}$ & $\begin{array}{c}84 \text { DCIS } \\
124 \text { stage } \\
\text { I } \\
47 \text { stage } \\
\text { IIA } \\
19 \text { stage } \\
\text { IIB } \\
3 \text { stage } \\
\text { IIIA }\end{array}$ & NR & $\begin{array}{l}121 \\
\text { positive, } \\
35 \\
\text { negative }\end{array}$ & $\begin{array}{c}73 \text { positive, } \\
42 \\
\text { negative }\end{array}$ & NR & & & 45.6 & 35 & 17 & 9 \\
\hline \multicolumn{15}{|l|}{ Summary } \\
\hline \multirow[t]{2}{*}{$\begin{array}{l}\text { Randomized } \\
\text { trials }\end{array}$} & HT & 225 & 56.07 & & 38 positive & 86 positive & & 33.19 & & 19.92 & 25.20 & 28 & 5 & 3 \\
\hline & No HT & 220 & 55.00 & & 31 positive & 73 positive & & 33.20 & & & 25.20 & 8 & 4 & 4 \\
\hline \multirow[t]{2}{*}{$\begin{array}{r}\text { Observation } \\
\text { al studies }\end{array}$} & HT & 1091 & 56.98 & & $\begin{array}{l}293 \\
\text { negative, } \\
87 \\
\text { positive }\end{array}$ & $\begin{array}{l}277 \\
\quad \text { positive, } \\
194 \\
\text { negative }\end{array}$ & $\begin{array}{l}230 \\
\text { positive, } \\
147 \\
\text { negative }\end{array}$ & 37.70 & 40.4 & 28.02 & 57.46 & 109 & 51 & 25 \\
\hline & No HT & 2619 & 60.87 & & $\begin{array}{l}737 \\
\text { negative, } \\
350 \\
\text { positive }\end{array}$ & $\begin{array}{l}625 \\
\quad \text { positive, } \\
440 \\
\text { negative }\end{array}$ & $\begin{array}{l}484 \\
\text { positive, } \\
346 \\
\text { negative }\end{array}$ & 54.01 & & & 57.02 & 443 & 409 & 195 \\
\hline \multirow[t]{2}{*}{ All } & HT & 1316 & 56.82 & & $\begin{array}{l}293 \\
\text { negative } \\
125 \\
\text { positive }\end{array}$ & $\begin{array}{c}363 \\
\quad \text { positive, } \\
194 \\
\text { negative }\end{array}$ & $\begin{array}{l}230 \\
\text { positive, } \\
147 \\
\text { negative }\end{array}$ & 36.93 & 40.4 & 26.58 & 53.03 & 137 & 56 & 28 \\
\hline & No HT & 2839 & 60.39 & & $\begin{array}{c}737 \\
\text { negative, } \\
381 \\
\text { positive }\end{array}$ & $\begin{array}{l}698 \\
\quad \text { positive, } \\
440 \\
\text { negative }\end{array}$ & $\begin{array}{l}484 \\
\text { positive, } \\
346 \\
\text { negative }\end{array}$ & 50.55 & & & 54.88 & 451 & 413 & 199 \\
\hline
\end{tabular}

aExcluding stage III/IV patients. bMedian value. 'Refers to hormone receptor status; specific data concerning estrogen receptor (ER) and progesterone receptor (PgR) status were not reported. dExcluding patients with ductal carcinoma in situ (DCIS). eWeighted mean. fFor recurrence only; follow-up for mortality was 55.2 months. gPersonal communication. hExcluding DCIS, stages III and IV, and ER-positive patients. DFI, diseasefree interval; HT, hormone therapy; NA, not able to calculate; NR, not reported.

recurrence, whereas estimates from randomized trials suggest the opposite. Because of statistically significant heterogeneity, these estimates should not be combined. Although all of the trials included in our analyses contained methodological weaknesses, the nonrandomized studies had design features that could introduce selection, reporting, and/or publication biases. The selection of healthier women to begin HT, the benefit of restaging before initiation of $\mathrm{HT}$, the short duration of $\mathrm{HT}$ exposure and follow up, the potential effects of HT on mammograms that could obscure the diagnosis of recurrent or new breast cancers, and publication bias favoring publication and/ or completion of studies reporting a protective effect of HT could explain the apparent protective effect of short-term HT on recurrence among breast cancer survivors in these studies.
Systematic serial restaging with blood tests and imaging during follow up is no longer generally recommended. However, their use detects breast cancer recurrence earlier. Balanced restaging was defined in only two out of seven observational studies. If breast cancer survivors contemplating HT use were more likely to have restaging, then the imbalance could account for the apparent protective effect of HT in observational studies. Although the description of prognostic factors was rarely complete, HT users in observational studies were younger and had more favorable prognostic profiles than did control individuals. This process also selected women with severe vasomotor symptoms, who have lower estradiol and testosterone levels; higher levels of these hormones have been associated with increased breast cancer risk. As a result, it is possible that women who were more likely to be offered $\mathrm{HT}$ [20] had lower recurrence risks. It is important to note that 
Figure 1

Relative Risks of Recurrent Breast Cancer associated with Hormone Therapy

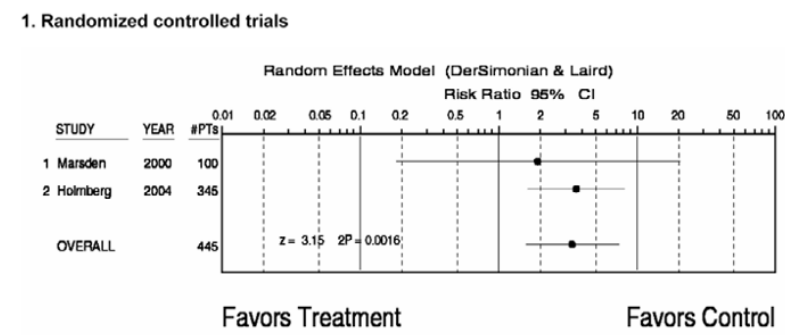

Overall Risk Ratio for $\mathrm{HT}$ use is $3.41,95 \% \mathrm{Cl} 1.59-7.33$ using random effect model; $\mathrm{Q}=0.25$ $\mathrm{Tau}^{2}<0.0001$

2. Observational Studies

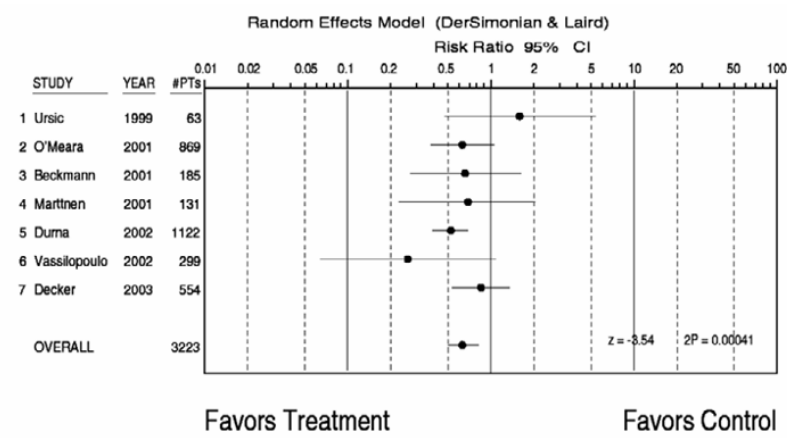

Overall Risk Ratio for $\mathrm{HT}$ use is $0.64,95 \% \mathrm{Cl} .50-.82$ using random effect model; $\mathrm{Q}=7.18$ $\mathrm{Tau}^{2}=0.0189$

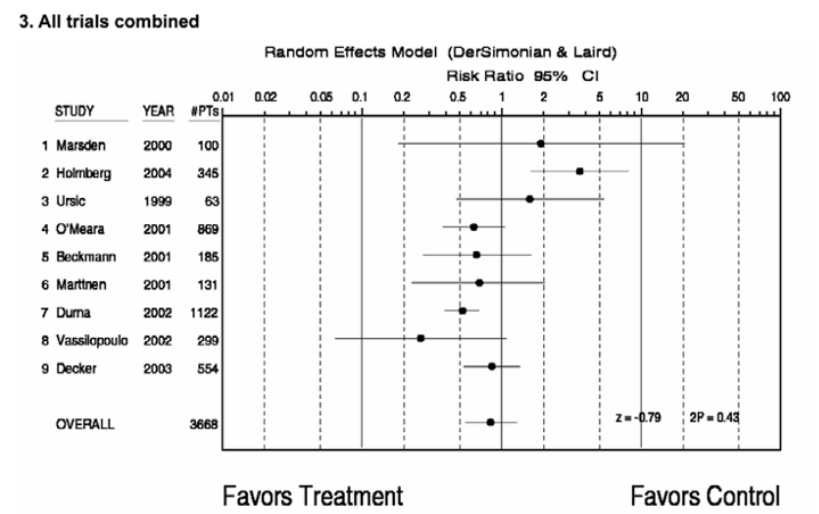

Overall Risk Ratio for $\mathrm{HT}$ use is $0.84,95 \% \mathrm{Cl} 0.54-1.30$ using random effect model; $\mathrm{Q}=25.33$ $\mathrm{Tau}^{2}=0.2448$

Relative risks for recurrent breast cancer associated with hormone therapy $(\mathrm{HT})$. Each black circle indicates the relative risk for recurrent breast cancer; the horizontal lines indicate the 95\% confidence interval (Cl). The top portion of the figure describes randomized controlled trials, the middle portion describes observational studies, and the bottom portion describes all trials combined. the majority of observational studies included in these analyses were not designed as observational studies from the start but rather as clinical experiences. Had these observational studies been more rigorously designed, using modern epidemiological techniques, many of these biases could have been minimized.

The adverse effect of combined HT on mammographic breast cancer detection [5] might have affected recurrence detection. Both recurrent and new breast cancers, which account for $10-20 \%$ of cancer events in women with prior lumpectomy, could have falsely appeared lower in HT users because of HT-related interference with mammographic diagnosis. However, this factor is probably not large, given the sharp increase in risk observed even after short-term HT use in randomized trials [36] and that the increase in risk pertained to distant as well as local recurrences.

The randomized trial reported by Holmberg and colleagues [9] overcomes many of the shortcomings of observational studies and provides the best available data on the impact of HT in breast cancer survivors. Although their unblinded design and lack of a placebo group could result in selective attrition, follow-up rates were comparable among HT users and nonusers. These investigators also reported summary interim analyses of a similar randomized trial, the Stockholm trial, with a relative hazard ratio of $0.82(95 \% \mathrm{Cl} 0.35-1.9)$. This trial was not included in this analysis because its findings have not yet been reported in full; the reasons for its discrepant findings are unclear at this time.

\section{Conclusion}

Observational studies of HT use in breast cancer survivors have design limitations that cannot be controlled for using standard statistical methods and hence should be considered essentially uninformative with respect to the safety of HT use in breast cancer survivors. Only randomized clinical trials are likely to provide reliable estimates of the effect of HT use in this setting.

\section{Competing interests}

The author(s) declare that they have no competing interests.

\section{Authors' contributions}

NC conceived the study (with RC), designed the study, reviewed the source studies, abstracted data, drafted the paper, and supervised the statistical analyses. JK participated in the design of the study and reviewed the source studies, abstracted data, carried out the meta-analysis, and helped to draft the manuscript. RC conceived of the study (with NC), designed the analysis, participated in its coordination, and helped to draft the manuscript. All authors read and approved the final manuscript. 


\section{Acknowledgements}

This work was supported, in part, by the Agency for Healthcare Quality (RO1 HS01332901), American Cancer Society Breast Cancer Prevention Forum, and the Robert Wood Johnson Foundation Generalist Physician Faculty Scholars Award (\#033958).

This work was presented at the 24th Annual Meeting of the Society for Medical Decision Making in Baltimore (MD, USA) in October 2002.

\section{References}

1. Carpenter J, Johnson D, Wagner L, Andrykowski M: Hot flashes and related outcomes in breast cancer survivors and matched comparison women. Nurs Forum 2002, 29:E16-E25.

2. MacLennan $A$, Lester $S$, Moore V: Oral estrogen replacement therapy versus placebo for hot flushes: a systematic review. Climacteric 2001, 4:58-74.

3. Pritchard $\mathrm{K}$, Khan $\mathrm{H}$, Levine $\mathrm{M}$, Steering Committee on Clinical Practice Guidelines for the Care and Treatment of Breast Cancer: Clinical practice guidelines for the care and treatment of breast cancer: The role of hormone replacement therapy in women with a previous diagnosis of breast cancer. CMAJ 2002, 166:1017-1022.

4. Collaborative Group on Hormonal Factors in Breast Cancer: Breast cancer and hormone replacement therapy: collaborative reanalysis of data from 51 epidemiological studies of 52,705 women with breast cancer and 108,411 without breast cancer. Lancet 1997, 350:1047-1059.

5. Chlebowski RT, Hendrix SL, Langer RD, Stefanick ML, Gass M, Lane D, Rodabough RJ, Gilligan MA, Cyr MG, Thomson CA, et al.: Influence of estrogen plus progestin on breast cancer and mammography in healthy postmenopausal women: the Women's Health Initiative Randomized Trial. JAMA 2003, 289:3243-3253.

6. Alving B: NIH asks participants in Women's Health Initiative estrogen-alone study to stop study pills, begin follow-up phase. NIH News 2004 [http://www.nhlbi.nih.gov/new/press/0403-02.htm]. (last accessed 19 April 2005).

7. Col NF, Hirota LK, Orr RK, Erban JK, Wong JB, Lau J: Hormone replacement therapy after breast cancer: a systematic review and quantitative assessment of risk. J Clin Oncol 2001, 19:2357-2363.

8. Chlebowski R, Col N: Menopausal hormone therapy after breast cancer. Lancet 2004, 363:410-411.

9. Holmberg L, Anderson H, for the HABITS steering and data monitoring committees: HABITS (hormonal replacement therapy after breast cancer - is it safe?), a randomised comparison: trial stopped. Lancet 2004, 363:453-455.

10. Eden JA, Wren BG: Hormone replacement therapy after breast cancer: a review. Cancer Treat Rev 1996, 22:335-343.

11. Eden JA, Bush T, Nand S, Wren BG: A case-control study of combined continuous estrogen-progestin replacement therapy among women with a personal history of breast cancer. Menopause 1995, 2:67-72.

12. Dew J, Eden J, Beller E, Magarey C, Schwartz P, Crea P, Wren B: A cohort study of hormone replacement therapy given to women previously treated for breast cancer. Climacteric 1998, 1:137-142.

13. Lau J: Metaanalyst. Boston, MA, USA.

14. Vassilopoulou-Sellin R, Asmar L, Hortobagyi GN, Klein MJ, McNeese M, Singletary SE, Theriault RL: Estrogen replacement therapy after localized breast cancer: clinical outcome of $\mathbf{3 1 9}$ women followed prospectively. J Clin Oncol 1999, 17:1482-1487

15. Beckmann MW, Jap D, Djahansouzi S, Nestle-Kramling C, Kuschel $B$, Dall P, Brumm C, Bender HG: Hormone replacement therapy after treatment of breast cancer: effects on postmenopausal symptoms, bone mineral density and recurrence rates. Oncology 2001, 60:199-206.

16. Durna EM, Crowe SM, Leader LR, Eden JA: Quality of life of breast cancer survivors: the impact of hormonal replacement therapy. Climacteric 2002, 5:266-276.

17. Natrajan $\mathrm{P}$ Soumakis $\mathrm{K}$, Gambrell R Jr: Estrogen replacement therapy in women with previous breast cancer. $A m$ J Obstet Gynecol 1999, 181:288-295.
18. Natrajan $P$, Gambrell R: Estrogen replacement therapy in patients with early breast cancer. Am J Obstet Gynecol 2002, 187:289-294.

19. Dew J, Wren B, Eden J: A cohort of topical vaginal estrogen therapy in women previously treated for breast cancer. Climacteric 2003, 6:45-52.

20. Marsden J, Whitehead M, A'Hern R, Baum M, Sacks N: Are randomized trials of hormone replacement therapy in symptomatic women with breast cancer feasible? Fertil Steril 2000 73:292-299.

21. Vassilopoulou-Sellin R, Cohen DS, Hortobagyi GN, Klein MJ, McNeese M, Singletary SE, Smith TL, Theriault RL: Estrogen replacement therapy for menopausal women with a history of breast carcinoma: results of a 5-year, prospective study. Cancer 2002, 95:1817-1826.

22. DiSaia $\mathrm{P}$, Brewster W, Ziogas A, Anton-Culver H: Breast cancer survival and hormone replacement therapy: a cohort analysis. Am J Clin Oncol 2000, 23:541-545.

23. Durna E, Wren B, Heller G, Leader L, Sjoblom P, Eden J: Hormone replacement therapy after a diagnosis of breast cancer: cancer recurrence and mortality. Med J Aust 2002, 177:347-351.

24. Beckmann MW, Jap D, Djahansouzi S, Nestle-Kramling C, Kuschel B, Dall P, Brumm C, Bender HG: Hormone replacement therapy after treatment of breast cancer: effects on postmenopausal symptoms, bone mineral density and recurrence rates. Oncology 2001, 60:199-206.

25. Decker DA, Pettinga JE, VanderVelde N, Huang RR, Kestin L, Burdakin $\mathrm{JH}$ : Estrogen replacement therapy in breast cancer survivors: a matched-controlled series. Menopause 2003, 10:277-285

26. Marttunnen M, Hietanen P, Pyrhonen S, Tiitinen A, Ylikorkala O: A prospective study on women with a history of breast cancer and with or without estrogen replacement therapy. Maturitas 2001, 39:217-225.

27. Ursic-Vrscaj M, Bebar S: A case-control study of hormone replacement therapy after primary surgical breast cancer treatment. Eur J Surg Oncol 1999, 25:146-151.

28. Smith TJ, Davidson NE, Schapira DV, Grunfeld E, Muss HB, Vogel VG III, Somerfield MR: American Society of Clinical Oncology 1998 update of recommended breast cancer surveillance guidelines. J Clin Oncol 1999, 17:1080-1082.

29. Temple LK, Wang EE, McLeod RS: Preventive health care, 1999 update: 3. Follow-up after breast cancer. Canadian Task Force on Preventive Health Care. CMAJ 1999, 161:1001-1008.

30. American Society of Clinical Oncology: Clinical practice guidelines for the use of tumor markers in breast and colorectal cancer. J Clin Oncol 1996, 14:2843 -2877.

31. Guthrie J, Dennerstein L, Hopper J, Burger H: Hot flushes, menstrual status, and hormone levels in a population-based sample of midlife women. Obstet Gynecol 1996, 88:437-442.

32. Overlie I, Moen M, Holte A, Finset A: Androgens and estrogens in relation to hot flashes during the menopausal transition Maturitas 2002, 41:69-77.

33. Cauley JA, Lucas FL, Kuller LH, Stone K, Browner W, Cummings SR: Elevated serum estradiol and testosterone concentrations are associated with a high risk for breast cancer. Study of Osteoporotic Fractures Research Group. Ann Intern Med 1999, 130:270-277.

34. Endogenous Hormones and Breast Cancer Collaborative Group: Endogenous sex hormones and breast cancer in postmenopausal women: reanalysis of nine prospective studies. $J$ Nat/ Cancer Inst 2002, 94:606-616.

35. Writing Group for the Women's Health Initiative Investigators: Risks and benefits of estrogen plus progestin in healthy postmenopausal women: principal results from the Women's Health Initiative randomized controlled trial. JAMA 2002, 288:321-333

36. O'Meara ES, Rossing MA, Daling JR, Elmore JG, Barlow WE, Weiss NS: Hormone replacement therapy after a diagnosis of breast cancer in relation to recurrence and mortality. I Natl Cancer Inst 2001, 93:754-762. 